\title{
Post-harvest storage of 'Paluma' guavas produced by plants fertirrigated with nitrogen and biofertilizer
}

\author{
Elisson Alves Santana ${ }^{*}{ }^{\circledR}$, Deisiele Diniz Lima ${ }^{2}$, Clériton de Souza $^{2}$, \\ Acácio Figueiredo $\mathrm{Neto}^{2}$, Ítalo Herbert Lucena Cavalcante ${ }^{2}$, Karla dos Santos Melo de Sousa ${ }^{\circledR}$
}

'Federal Rural University of the Semi-Arid, Mossoró, Brazil
${ }^{2}$ Federal University of São Francisco Valley, Petrolina, Brazil
${ }^{*}$ Corresponding author, e-mail: alves.agro@outlook.com

\begin{abstract}
The association between mineral fertilizer and biofertilizers can contribute to guavas quality. An experiment was carried out in order to assess, over the days, 'Paluma' guavas physical-chemical quality in function of nitrogen fertilizer and biofertilizer doses. It was adopted a randomized blocks with treatments distributed in a factorial $5 \times 2 \times 5$ referring to evaluation days post-harvest $(0,3,6,9$ and 12), nitrogen fertilization (50 and 100\% culture recommendation) and application of bovine biofertilizer doses by fertigation (0.0, 2.5, 5.0, 7.5 and 10.0\%). The physical-chemical quality of 'Paluma' guava fruit was influenced by the association between liquid bovine biofertilizer and nitrogen fertilization. This combination increased soluble solids, titratable acidity, ratio, vitamin C, pH, firmness and loss of fresh mass, but did not affect the pulp percentage. The bovine biofertilizer, together with mineral fertilization, is important to increase the post-harvest quality of 'Paluma' guava.
\end{abstract}

Keywords: irrigated fruticulture, organic fertilizers, Psidium guajava, physical and chemical properties, semiarid climate

\section{Introduction}

The irrigated poles in the Northeast of Brazil have water and edaphoclimatic conditions suitable for growing fruit trees, making this region one of the largest guava producers especially in the São Francisco Valley, which is responsible for almost $43 \%$ of the total Guava produced in Brazil (IBGE, 2017).

The productivity of high-quality fruits is a consequence of factors related to climatic conditions, soil, irrigation and nutritional balance (Santana et al., 2017). However, the nutritional affects not only the productivity, but also quality of the fruit in terms of size, weight and post-harvest conservation (D'Egidio et al., 2019).

To supply guava tree nutritional demand and reach high yields, high fertilizer applications are required (Natale, 2009). The combination between mineral and organic fertilizers can reduce production costs by as well as reducing environmental impacts by avoiding the phytotoxic effects of mineral fertilizers high doses that may unbalance the relationships between nutrients and salinize the soil (Sediyama et al., 2009). The biofertilizer can have an effect on vegetative and productive plants development, on the qualitative parameters of the production and still be able to reduce the depressive effects of the salinity of the soil or water (Dias et al., 2011). Despite the promising results regarding biofertilizer use in agriculture (Dias et al., 2011; Santos et al., 2014; Nascimento et al., 2015; Santana et al., 2017), studies on the combination of nitrogen fertilizer and biofertilizer and the influence on the physical and chemical quality of guavas are still scarce in the literature, especially related to storage time. The aim of this work was to evaluate the quality of guava fruits produced as a function of nitrogen fertilization, biofertilizer fertirrigation and different storage days at room temperature. 


\section{Material and Methods}

The study was carried out in April of 2016, on the experimental farm of Federal University of São Francisco Valley, Petrolina PE, Brazil. The climate of this region was classified as Bswh (Köeppen), which corresponds to a semi-arid region. In this study was used one-year-old guava (Psidium guajava) plants cv. Paluma with, spaced $4 \times 4$ meters, they were daily irrigated by micro-sprinkle and fertigated.

The biofertilizer consisted of water and fresh bovine manure under anaerobic fermentation, according to Santana et al. (2017) recommendations. It presented $0.72 \mathrm{~g} \mathrm{dm}^{-3}$ of $\mathrm{N}, 0.04 \mathrm{~g} \mathrm{dm}^{-3}$ of $\mathrm{P}, 0.50 \mathrm{~g} \mathrm{dm}^{-3}$ of $\mathrm{K}, 0.20 \mathrm{~g} \mathrm{dm}^{-3}$ of $\mathrm{Ca}, 0.12 \mathrm{~g} \mathrm{dm}^{-3}$ of $\mathrm{Mg}$ and $0.39 \mathrm{~g} \mathrm{dm}^{-3}$ of $S$ in your composition. Biofertilizer was biweekly applied by fertirrigation water and ratio according to each treatment but firming the amount of $2.4 \mathrm{~L} \mathrm{~m}^{-2}$ of plant canopy as proposed by Santana et al. (2017).

The experimental design was randomized blocks with treatments distributed in a factorial arrangement $(5 \mathrm{x}$ $2 \times 5)$ referring to biofertilizer concentrations $(0,2.5,5.0,7.5$ and $10 \%$ of the fertirrigated volume), The mineral fertilizing with $\mathrm{N}$ (fertilization with $50 \%$ and $100 \%$ of $\mathrm{N}$ recommended by Natale (2009)), was applied using as source a formulated fertilizer composed of $12 \% \mathrm{~N}, 5 \% \mathrm{P}, 11 \% \mathrm{~K}$, $13.1 \% \mathrm{Ca}$ and $0.2 \% \mathrm{~B}$, and evaluation times after harvest $(0,3,6,9$ and 12 days after harvest at room temperature) with four replications of five plants each. Guavas were harvested at stage 1 of maturation (Cavalini et al., 2015) and fifteen fruits was selected for each treatment. Storage ambient temperature was set in $\left(24 \pm 1^{\circ} \mathrm{C}\right)$ and relative humidity around $(70 \pm 5 \%)$, until reaching the end of the commercialization period, that according to Cavalini et al. (2015) is defined by completely yellow color of the bark, firmness of pulp less than $15 \mathrm{~N}$ and presence of rot in $15 \%$ of the fruit.

The fruit analyses followed the Instituto Adolfo Lutz (2008) instructions and included the parameters: i) weight loss, measured using a brand precision balance and expressed in $\mathrm{g}$; and the fruits were weighed at $0,3,6,9$ and 12 days after harvest ii) fruit firmness (N), measured using a fruit hardness tester; iii) percentage of pulp with seed; iv) titratable acidity (TA) expressed in $\mathrm{g}$ of acid citric $100 \mathrm{~g}$ of pulp ${ }^{-1}, 5.0 \mathrm{ml}$ of guava pulp was weighed and then diluted into distilled water to give a final volume of $50 \mathrm{ml}$. In this solution was added 2 drops of the phenolphthalein indicator and titrated with $0.1 \mathrm{~N}$ sodium hydroxide ( $\mathrm{NaOH}$ ); v) soluble solids (SS), expressed as ${ }^{\circ}$ Brix; were measured using an $\mathrm{Abbe}^{\circledR}$ refractometer; vi) vitamin $C$ followed iodimetric method and expressed in $\mathrm{mg} 100 \mathrm{~g}$ of fresh fruit-1, which $5 \mathrm{~g}$ of fruit pulp was taken from guava and brought to a final volume of $100 \mathrm{~mL}$ by adding distilled water plus $1 \mathrm{~mL}$ of $1 \%$ amid solution. A 20 $\mathrm{mL}$ sample was taken from the mixture and titrated with $1 \mathrm{~N}$ iodine; vii) pulp $\mathrm{pH}$, measured using a Marconi ${ }^{\circledR} \mathrm{pH}$ meter; viii) relation between the soluble solids and the titratable acidity (SS/TA ratio) was calculated. Results was submitted to variance analysis to evaluate the significant effect between days, nitrogen fertilization and biofertilizer doses by $\mathrm{F}$ test in the statistical program ASSISTAT 7.7 Beta. For quantitative treatments a multiple regression analysis was applied.

\section{Results and Discussion}

The factors studied (days after harvest (DPH), nitrogen fertilization (N) and biofertilizer doses (Bio)) significantly influenced all variables evaluated, except firmness of pulp, which presented only double interaction ( $\mathrm{N} \times \mathrm{Bio})$ (Table 1).

\section{Soluble solids}

Although interaction among treatments, only the double interaction has adjustment to regression models. The fruits produced without biofertilizer, under $100 \% \mathrm{~N}$ fertilization showed higher or the highest SS compared to $50 \% \mathrm{~N}$ fertilization (Table 1).

During post-harvest or along the post-harvest, the SS increased from 9.8 to $10.5^{\circ}$ Brix $(100 \% \mathrm{~N})$ and 7.7 from $9.15^{\circ}$ Brix ( $50 \% \mathrm{~N}$ ) (Figure 1). In this work, the values are higher than those reported by Alencar et al. (2016), who found values were 7.95 and $9.26^{\circ}$ Brix, working at different times and doses of potassium, and close those found by Brackmann et al. (2012) with values ranging from 7.26 to $8.12^{\circ}$ Brix, evaluating controlled atmosphere for guava storage, both working with 'Paluma' guavas. According to Santos et al. (2014), organic fertilization promotes higher levels of soluble solids, which have occurred in the present work. Furthermore, probably the $100 \% \mathrm{~N}$ dose presented higher values for the $\mathrm{N}$ effects in the leaves sugar biosynthesis, so that concentration of soluble solids may increase due to translocation of the sugar from leaves to the fruit (Ramos et al., 2010). Andy possibly, the increase in the absorption of $\mathrm{N}$ provided a rise in the absorption of $K$, since the most common interaction of $\mathrm{N}$ occurs with $\mathrm{K}$, in which the increment of one favors the accumulation of the other (Foloni et al., 2013). This increase in the concentration of sugars in the fruit may have been due to the role that $K$ plays in the apoplastic co-transport during the sucrose charge from the mesophile to the phloem, mediate by ATPase enzymes. The highest level of SS usually obtained in fruits 
with the highest concentrations of $\mathrm{K}$ (Bouzo et al., 2018).

The nitrogen fertilization associated to biofertilizer doses produced, initially, fruits with lower SS. This may have occurred because the fruits were harvested at stage 1 of maturation, based on the dark green color of the peel, according to a scale proposed by Cavalini et al. (2015). According to the same author, 'Paluma' guava fruits tend to be more acid when harvested in the early stages of ripening. This resulted in a decrease in the SS in the initial fruits, and with the advance of the maturation process, the SS can be increased (Figure 1A and B). However, during the guavas storage there was oBrix increase, reaching close to and even higher values than those obtained without biofertilizer on $12^{\text {th }}$ day of storage. It is important to note that $50 \% \mathrm{~N}$ fertilization + $10 \%$ Bio was the one that still showed growth in the obrix at the 12th day of storage, demonstrating that these fruits had not yet reached full maturation during the maximum storage period.

Table 1. Soluble solids (SS), titratable acidity (TA), ratio (SS/TA), vitamin C (Vit. C), pH, \% of pulp with seed, firmness (Firm.) and loss of weight (LW) of 'Paluma' guavas as a function of storage days (DPH), nitrogen fertilization (N) and biofertilizer doses (Bio.)

\begin{tabular}{|c|c|c|c|c|c|c|c|}
\hline & SS & TA & SS/TA & Vit. C & $\mathrm{pH}$ & Firm. & LW (\%) \\
\hline DPH ('F' value) & $6459.271^{* *}$ & $2913.225^{* *}$ & $4635.684^{* *}$ & $263.482^{* *}$ & $604.264^{* *}$ & $8.770 * *$ & $33.281^{* *}$ \\
\hline Msd & 0.0300 & 0.0089 & 0.2079 & 536.87 & 0.0259 & 30.975 & 4.767 \\
\hline CV. \% (DPH) & 0.37 & 1.6 & 1.64 & 7.98 & 0.83 & 101.64 & 40.38 \\
\hline N ('F' value) & $19489.080^{* *}$ & $49.829 * *$ & $602.332^{* *}$ & $7.234^{*}$ & $63.469^{* *}$ & $7.688^{*}$ & $15.364^{*}$ \\
\hline $50 \%$ & $9.186 \mathrm{~b}$ & $0.654 \mathrm{~b}$ & $1.450 .597 \mathrm{~b}$ & $79.940 \mathrm{a}$ & $3.71547 a$ & $32.041 \mathrm{~b}$ & $13.361 \mathrm{~b}$ \\
\hline $100 \%$ & $9.992 \mathrm{a}$ & $0.665 a$ & $1.533 .612 a$ & $78.192 \mathrm{~b}$ & $3.644 \mathrm{~b}$ & $39.602 a$ & $15.190 \mathrm{a}$ \\
\hline Msd & 0.0128 & 0.0036 & 0.07534 & 1447 & 0.0198 & 6.0739 & 1.0757 \\
\hline CV. \% (N) & 0.37 & 1.52 & 1.39 & 5.03 & 1.48 & 46.62 & 17.9 \\
\hline Bio ('F' value) & 2937.299 ** & 103.511 ** & $264.727^{* *}$ & $6.4267^{* *}$ & $11.852^{* *}$ & $1.695 \mathrm{~ns}$ & $18.457^{* *}$ \\
\hline Msd & 0.0208 & 0.00652 & 0.140 & 241.541 & 0.0284 & 14.4012 & 2.829 \\
\hline CV. \% (Bio) & 0.28 & 1.37 & 1.30 & 4.24 & 1.07 & 55.75 & 24.44 \\
\hline \multicolumn{8}{|c|}{ Interaction ('F' value) } \\
\hline $\mathrm{N} \times$ Bio & $11027.844^{* *}$ & $136.979 * *$ & $347.371 * *$ & $7.217^{* *}$ & $70.477^{* *}$ & $3.947 * *$ & $3.783 * *$ \\
\hline DPH $x$ Bio & $1418.284^{* *}$ & $80.272^{* *}$ & $202.187^{* *}$ & $19.248^{* *}$ & $6.920^{* *}$ & $0.649 \mathrm{~ns}$ & $0.172^{* *}$ \\
\hline $\mathrm{DPH} \times \mathrm{N}$ & $727.476^{* *}$ & $50.425^{* *}$ & $115.175^{* *}$ & $6.942 * *$ & $4.735^{*}$ & $1.450 \mathrm{~ns}$ & $0.488 \mathrm{~ns}$ \\
\hline DPH $\times$ N $\times$ Bio & $2439.472^{* *}$ & $25.063^{* *}$ & $69.173^{* *}$ & $16.048^{* *}$ & $7.656^{* *}$ & $1.573 \mathrm{~ns}$ & $0.066^{* *}$ \\
\hline
\end{tabular}

\section{(A)}

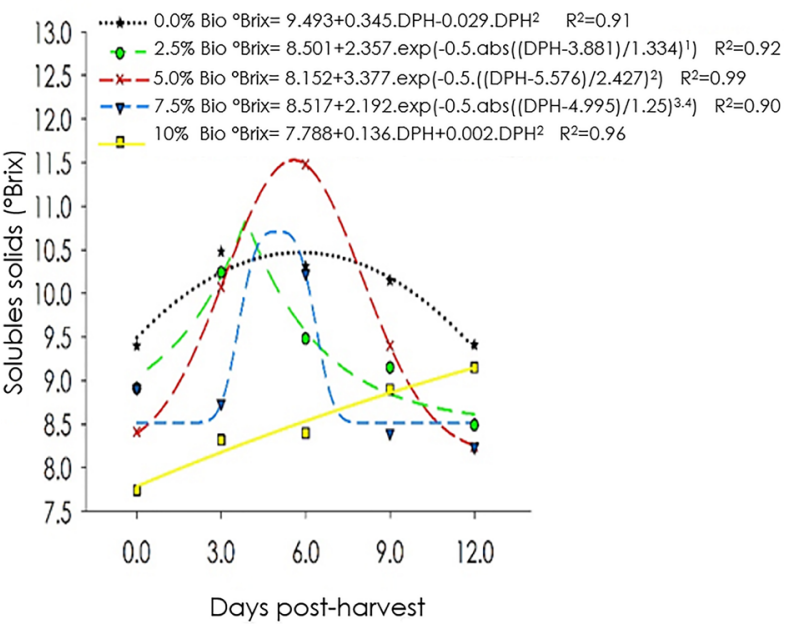

(B)

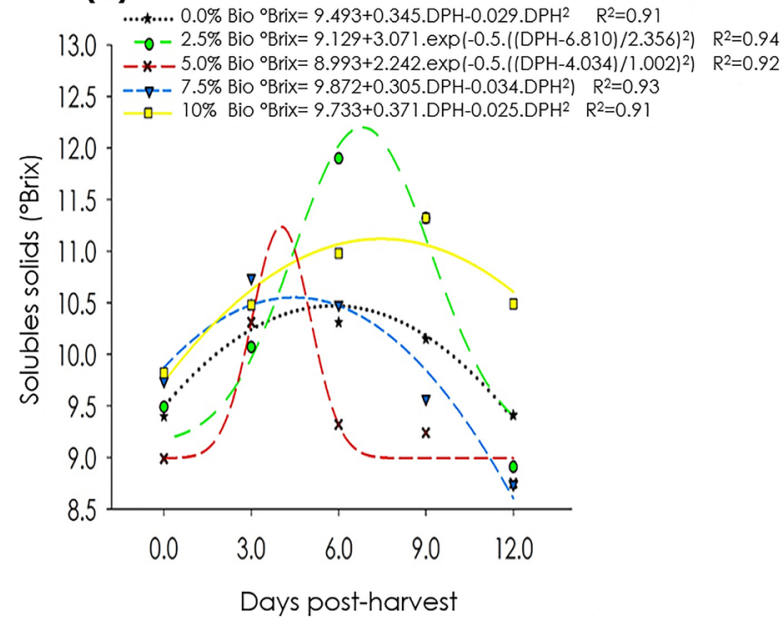

Figure 1. 'Paluma' guava soluble solids in function of post-harvest time, doses of biofertilizer and nitrogen fertilization $50 \%$ (A) and $100 \%(B)$.

Titratable acidity

Fruits from fertigated plants with 100\% $\mathrm{N}$ had average titratable acidity between 0.71 and $0.64 \mathrm{~g}$ citric acid $100 \mathrm{~g}$ of pulp $\mathrm{p}^{-1}$ (Figure $2 \mathrm{~B}$ ) and in the fertilization with $50 \% \mathrm{~N}$, the values found was between 0.72 and $0.59 \mathrm{~g}$ citric acid $100 \mathrm{~g}$ of pulp ${ }^{-1}$ (Figure 2A).
The values are higher than those reported by Malta et al. (2013) that ranged between 0.41 and $0.53 \mathrm{~g}$ citric acid $100 \mathrm{~g}$ of $\mathrm{pulp}^{-1}$ in 'Paluma' guava under organic and mineral fertilization. In general, fruits titratable acidity decreased over the post-harvest times (Figure $2 \mathrm{~A}$ and $\mathrm{B}$ ) in consequence of fruit maturation. This 
behavior is expected because the reduction of organic acids presents in the fruits are result of fruits respiration (Andrade Júnior et al., 2016). In the fertilization with 100\% $\mathrm{N}$, there was increase in the TA directly proportional to the doses of biofertilizer (Figure $2 \mathrm{~B}$ ), which may be linked to biofertilizer chemical composition, because the organic acids present in biofertilizer can improve fruits titratable

\section{(A)}

$\mathrm{TA}=0.7263-0.0073$.days-0.0088. bio +0.0001. days $^{2}+0.0002$. bio $^{2}$ $\mathrm{R}^{2}=0.99$

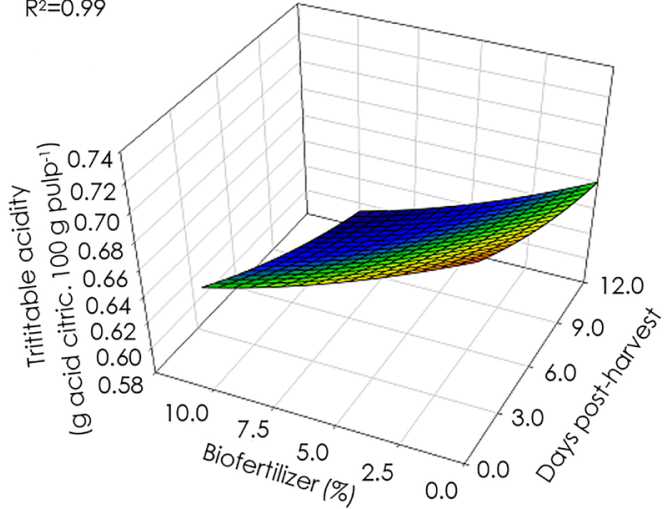

(C) Ratio $=12.8788+0.1352$.days +0.1622 .bio

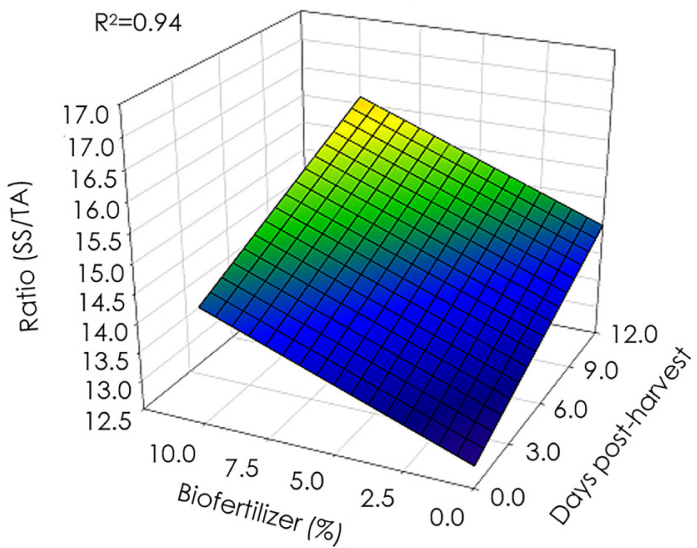

acidity (Santos et al., 2014). For treatments associated to $50 \%$ of $\mathrm{N}$ fertilization, it was verified more pronounced decrease of acid values when compared to those with $100 \% \mathrm{~N}$ fertilization (Figure 2). All the average values of TA found are higher than the minimum value required by current legislation in Brazil, which is $0.4 \%$ (MAPA, 2000).

\section{(B)}

$T A=0.7127-0.0073 \cdot$ days $-0.0088 \cdot$ bio $+0.0004 \cdot$ days $2+0.0005 \cdot$ bio $^{2}$ $\mathrm{R}^{2}=0.98$

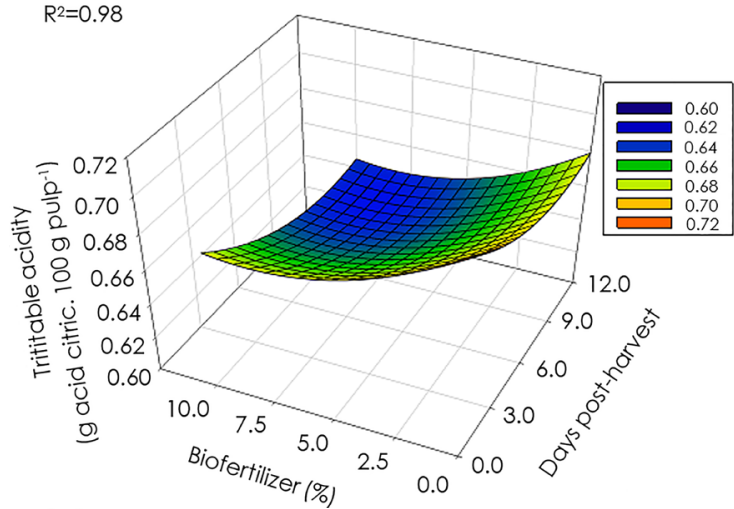

(D) Ratio $=13.8136+0.1265$.days+0.1518.bio

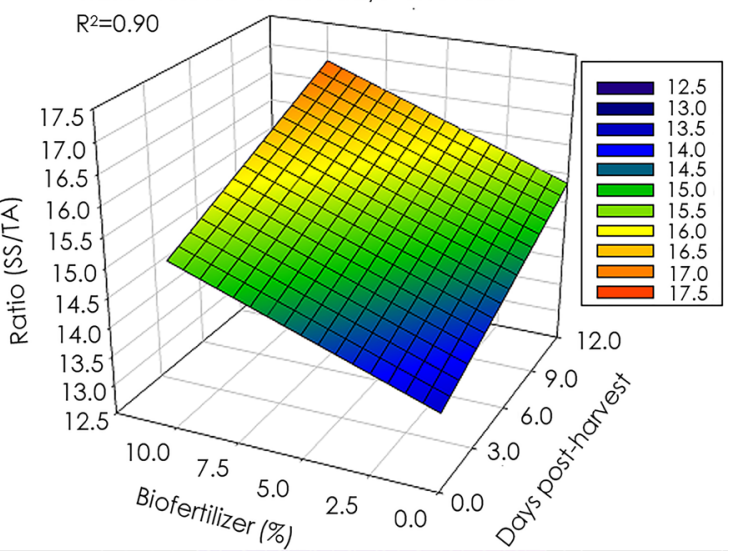

Figure 2. 'Paluma' guava trititable acidity in function of post-harvest time, doses of biofertilizer and nitrogen fertilization $50 \%$ (A) and $100 \%$ (B) and ratio post-harvest times, doses of biofertilizer and nitrogen fertilization 50 $\%(C)$ and $100 \%$ (D).

Ratio (SS/TA)

The fruits from plants grown under $100 \% \mathrm{~N}$ fertilization and biofertilizer presented superiority over $50 \% \mathrm{~N}$ fertilization (Table 1). Ratio average recorded for treatments with 50 and $100 \% \mathrm{~N}$ ranged from 13.12 to 16.23 and from 13.58 to 17.00, respectively (Figure 2C and D) and they are lower than those reported by Batista et al. (2015) that was 18.87 when evaluating guava fruits quality. For treatments with 50 and $100 \%$ of $\mathrm{N}$ fertilization there was a linear increase to the ratio. About biofertilizer rates, the highest ratio values were record to $10 \%$ concentration and on the twelfth day of evaluation, proving that there was an increase in the SS content and reduction of TA over the time. Any of the treatments applied provided the guava Ratio values close to the minimum required by the current Brazil legislation, which is 17.5 (MAPA, 2000).

\section{Vitamin C}

The highest value was found to $50 \%$ of $\mathrm{N}$ (Table 1), whose average ranged from 69.86 to $92.24 \mathrm{mg}$ of ascorbic acid $100 \mathrm{~mL}$ of pulp ${ }^{-1}$ (Figure 3A), and for $100 \%$ $\mathrm{N}$ fertilization the values ranged between 67.9 and 86.36 $\mathrm{mg}$ of ascorbic acid $100 \mathrm{~mL}$ of pulp ${ }^{-1}$ (Figure 3B). The values are close to those found by Lima et al. (2008) who reported a value of $89.78 \mathrm{mg}$ of ascorbic acid. $100 \mathrm{~mL}$ of pulp ${ }^{-1}$, and Santana et al. (2017) whose values ranged from 70.08 to $79.88 \mathrm{mg}$ of ascorbic acid. $100 \mathrm{~mL}$ of pulp ${ }^{-1}$, both working with 'Paluma' guavas variety.

In general, vitamin $C$ increased over the days reaching maximum mean values between the ninth and eleventh evaluation days. According to Machado et al. (2019) in the first maturation stage of guavas there is a tendency to increase the vitamin $C$ content as the 
maturation proceeds until it stabilizes and begins to decrease. Concerning the interaction among DPH $x \mathrm{~N} x$ Bio with $100 \%$ of $N$ (Figure $3 B$ ), the best biofertilizer rate was $7.5 \%$, increase $2.55 \%$ in relation to the control, but only in the twelfth day of evaluation. The association between $50 \% \mathrm{~N}$ and $7.5 \%$ is responsible for the highest concentration of ascorbic acid on the ninth day of

(A)

A.A $=392.9315 . \exp \left(-0.5 .\left((\text { days-16.9632)/29.7461) })^{2+}(\right.\right.$ (bio(14.1389)/247857/2)!

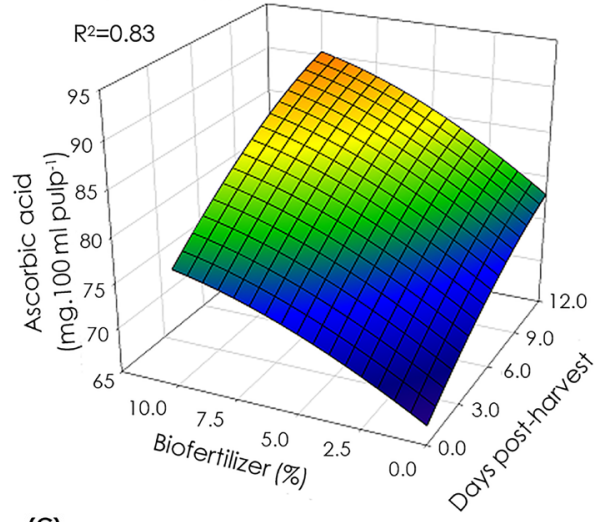

(C)

$\mathrm{pH}=3.5525-0.0067 \cdot$ days $+0.0042 \cdot \mathrm{bio}+0.0029 \cdot$ days $^{2}+0.0007 \cdot$ bio $^{2}$

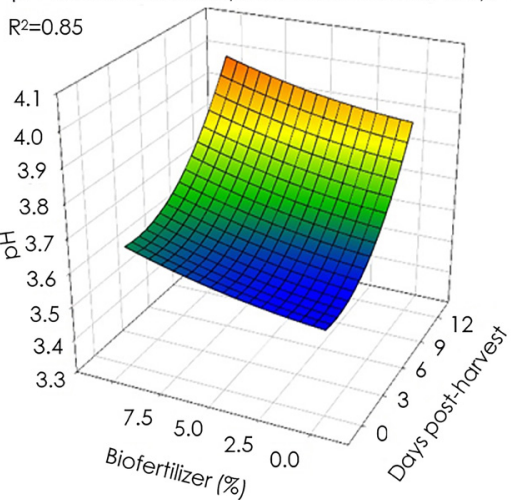

evaluation, increasing to $24.82 \%$ ascorbic acid content in relation to the control. Application of bovine biofertilizer has a positive influence on the vitamin C (Nascimento et al., 2015), this probably happens due to organic acids and sugars that are present in organic sources and can increase the vitamin $\mathrm{C}$ content in the fruits.

(B)

A. $A=68.8799+0.6831$. days +0.8198. bio +0.0103. days $^{2+}+$ 0.0148. days $^{2}$

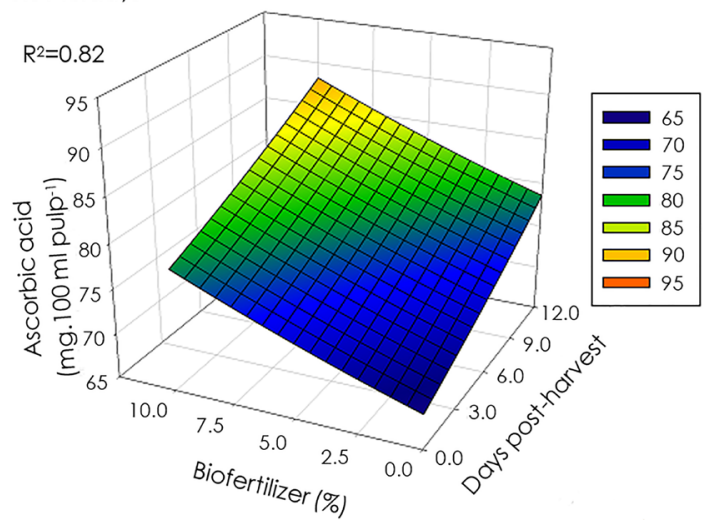

(D)

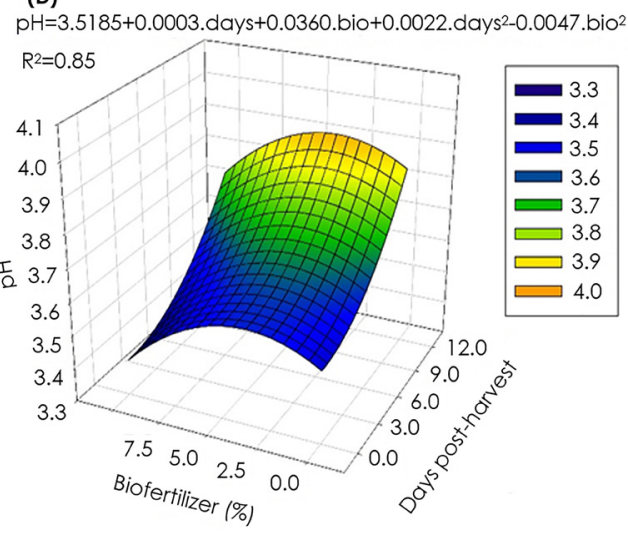

Figure 3. 'Paluma' guavas Ascorbic acid depending to days post-harvest, nitrogen ferilizization $50 \%$ (A) and $100 \%$ (B) and dose of biofertilizer; $\mathrm{pH}$ depending to days post-harvest, nitrogen ferilizization $50 \%$ (C) and $100 \%(D)$ and dose of biofertilizer.

$\mathrm{PH}$

The treatment with $50 \% \mathrm{~N}$ and biofertilizer presented higher $\mathrm{pH}$ values (Table 1). The averages recorded for $100 \%$ and $50 \% \mathrm{~N}$ with biofertilizer varied from 3.59 to 3.73 and from 3.62 to 3.84 , respectively (Figure $3 \mathrm{C}$ and $\mathrm{D})$. These values are close to those found by Amorim et al. (2015) which were between 3.72 and 3.88 but are lower than values reported by Batista et al. (2015) between 3.92 and 4.0 to the same variety.

The treatments with biofertilizer increased the fruits $\mathrm{pH}$ in relation to the control, however, it was verified oscillation in the $\mathrm{pH}$ values with the rise of the doses. Only the treatment with $100 \% \mathrm{~N}$ and $10 \%$ of biofertilizer provided the lowest values and $\mathrm{pH}$ variation from the first until the last day of evaluation. This behavior is connected to higher tritable acidity for the same biofertilizer dose, as seen previously, been these parameters inversely proportional (Amarante et al., 2013). Regardless of the treatment applied, all fruits presented $\mathrm{pH}$ values under limit value of Brazilian legislation, which is 4.2 (MAPA, 2000). The lowest values of $\mathrm{pH}$ indicate that the fruit has a higher content of organic acids and, hence, it will reflect in the fruit conservation, making it less susceptible to this consequently will deterioration in post-harvest (Amarante et al., 2013).

\section{Weight loss}

The mass losses were increasing over evaluation days (Figure 4A and B) and the fertilization with $100 \% \mathrm{~N}$ promoted higher loss of fresh mass than $50 \%$ of $\mathrm{N}$ (Table 1).The treatments with 50 and $100 \% \mathrm{~N}$ associated to $7.5 \%$ biofertilizer dose were that promoted the lower losses of 
fruit fresh mass in the ninth days of evaluation (9.97\%) and (13.73\%), respectively. It is probable that the components present in the biofertilizer contributed to a delay in the loss of fresh guava as Calcium $\left(0.20 \mathrm{mg} \mathrm{dm}^{-3}\right)$. The calcium reduces the respiration rates, pectin degradation and changes in fruit tissues (Bouzo et al., 2018). Although fresh

(A)

$\operatorname{Loss}(\%)=5.1814+0.5125$. days +0.6151 .days-0.0060. days ${ }^{2-}$ $0.0086 . \mathrm{bio}^{2}$

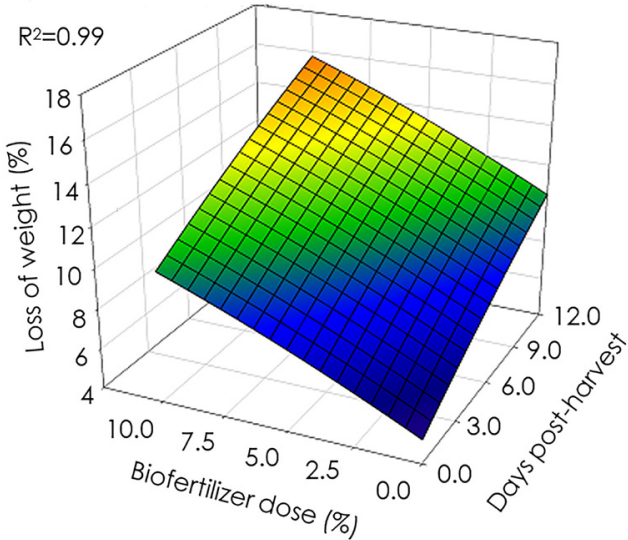

mass loss has been $20.10 \%(50 \% \mathrm{~N})$ and $(100 \% \mathrm{~N})$ on the twelfth day of storage, the values presented are close than those reported by Onias et al. (2018) that was up to $25 \%$ in 'Paluma' guavas stored in ambient condition and by Cavalini et al. (2015) in work on harvesting point and quality of 'Kumagai' and 'Paluma'.

(B)

$\operatorname{Loss}(\%)=4.7767+1.0231$. days $+1.2277 \cdot$ bio-0.0754.days20.0654.bio2

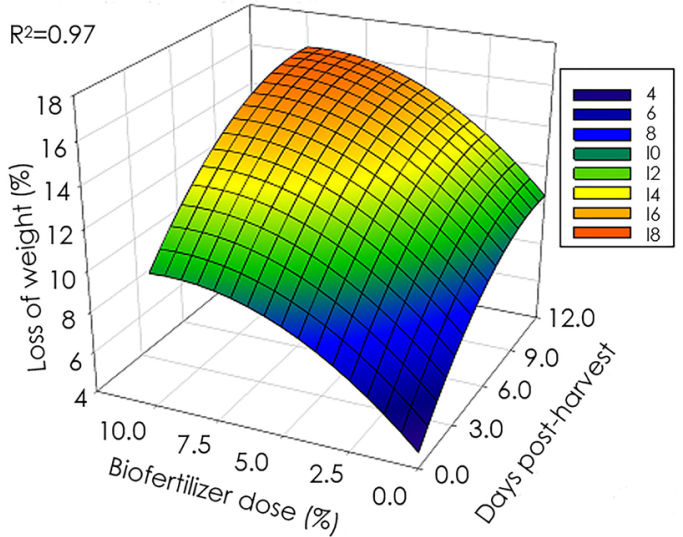

Figure 4. 'Paluma' guavas loss of weight post-harvest times, doses of biofertilizer, nitrogen fertilization $50 \%$ (A) and $100 \%$ (B).

Firmness of pulp

It was observed superiority of the treatments with $100 \% \mathrm{~N}$, whose values ranged from 43.69 (control) to 47.69 N (10\% biofertilizer) (Figure 5).

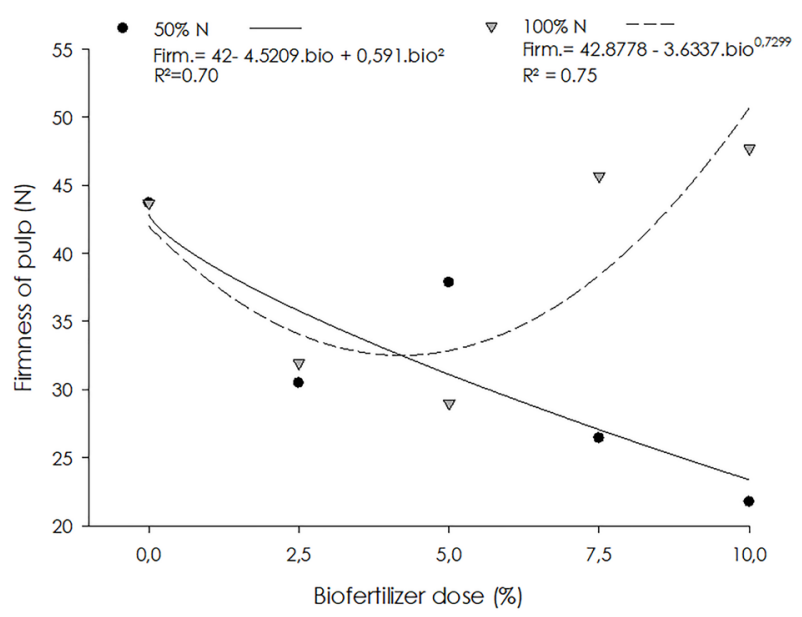

Figure 5. 'Paluma' guavas firmness of pulp under nitrogen fertilization and doses of biofertilizer

These values are lower than that found by PérezBarraza et al. (2015), that ranging from 86.5 to $191.2 \mathrm{~N}$ for 'Paluma' guava. On the other hand, Batista et al. (2015) found lower pulp firmness values, approximately $20 \mathrm{~N}$ for mature guavas, maintained in the same condition of this experiment. As can be seen in Figure 4, from the $5 \%$ biofertilizer dose and $100 \%$ of $\mathrm{N}$ there was increase in firmness of the pulp, while at the rate of $50 \%$ of $\mathrm{N}$ it was observed reverse effect. Nascimento et al. (2015) in a study with biofertilizer and mineral fertilization in the quality of passion fruit found the highest values of pulp firmness in the treatments where mineral fertilization was supplied with NPK and firmness tended to increase with the growing biofertilizer dose.

The superior performance for the $100 \% \mathrm{~N}$ treatment may have influenced by the presence of high levels of potassium and calcium in the biofertilizer used in this experiment $10.50 \mathrm{mg} \mathrm{dm}^{-3}$ and $0.20 \mathrm{mg} \mathrm{dm}^{-3}$ respectively). The potassium promotes, as result of the translocation of sugars, increase in mass, flavor, and aroma due to maintenance of cellular turgescence and also contributes to the fruits resistance (Rogier et al., 2017). In addition, calcium also has an influence on the firmness because is part of the middle lamella cellular, thus, reduction of water loss, leading to better fruit quality and longer post-harvest storage period (Bouzo, et al., 2018). These aspects may have favored increasing the firmness of the pulp as the biofertilizer growing doses, with a maximum value recorded for the $10 \%$ biofertilizer (47.69 N).

In addition to this, the 'Paluma' guava fruits treated with fertilization of $50 \%$ and $100 \%$ and doses of biofertilizer, presented better appearance compared with control treatment (Figure 6A and B). It is observed that until the ninth day of evaluation, the fruits still had a healthy aspect, and although ripe, they in natura be consumed especially those treated with the highest 
doses of biofertilizer. This could be an indicator that the combination of nitrogen fertilization and biofertilizer can

(A)

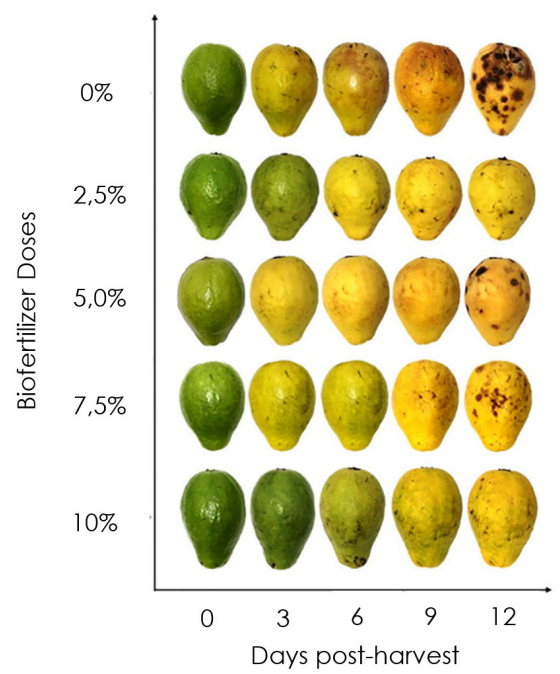

Figure 6. 'Paluma' guavas biofertilizer doses, post-harvest times, nitrogen fertilization $50 \%(A)$ and $100 \%(B)$.

\section{Conclusions}

The results of this research indicate that: i) the quality of 'Paluma' guava fruit stored under ambient temperature is influenced by the bovine biofertilizer and nitrogen fertilization; ii) the bovine biofertilizer increased the chemical parameters (soluble solids, titratable acidity, ratio, vitamin $\mathrm{C}$ and $\mathrm{pH}$ ) and physical (firmness of pulp and decreases weight loss), of guavas; iii) In general, the 10 $\%$ biofertilizer dose provides the best post-harvest, mainly when associated with $50 \% \mathrm{~N}$ fertilization. Furthermore, this combination reduces the synthetic fertilization; iv) the combination of biofertilizer and nitrogen fertilization conduced the guavas to nine days of shelf-life under environment condition.

\section{References}

Alencar, R.D., Leite, G.A., Mendonça, V., Lima, F.V., Pereira, G.A., Farias, W.C. 2016. Adubação potássica na produção e qualidade pós-colheita de goiaba 'Paluma' no semiárido potiguar. Comunicata Scientiae 7: 139-148.

Amarante, C.V.T., Steffens, C.A., Benincá, T.D.T., Hackbarth, C., Santos, K.L. 2013. Qualidade e potencial de conservação pós-colheita dos frutos em cultivares brasileiras de goiabeira-serrana. Revista Brasileira de Fruticultura 35: 990-999.

Amorim, D.A., Rozane, D.E., Souza, H.A., Modesto, V.C., Natale, W. 2015. Adubação nitrogenada e potássica em goiabeiras 'Paluma': I. Efeito na produtividade e na qualidade dos frutos para industrialização. Revista Brasileira de Fruticultura 37: 201-209.

Andrade Júnior, V.C., Guimarães, A.G., Azevedo, A.M., Pinto, N.A.V.D., Ferreira, M.A.M. 2016. Conservação favor the conservation of the fruits of 'Paluma' guava, even under storage conditions at room temperature.

(B)

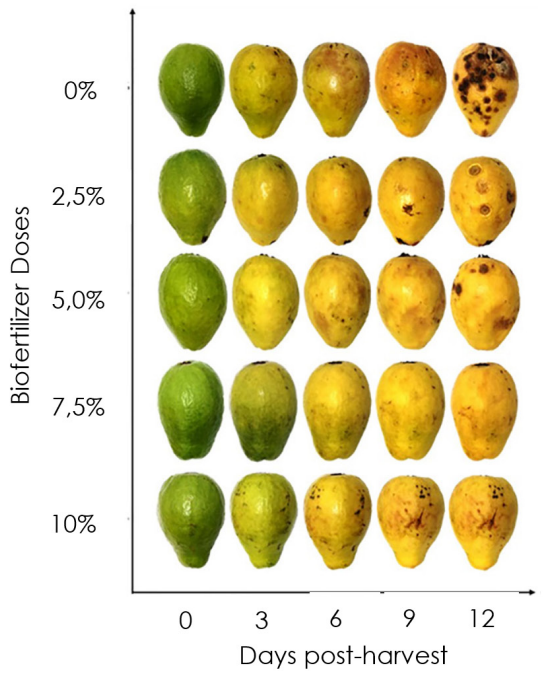

pós-colheita de frutos de morangueiro em diferentes condições de armazenamento. Horticultura Brasileira 34: 405-411.

Batista, P.F., Lima, M.A.C., Trindade, D.C.G., Alves, R.E. 2015. Quality of different tropical fruit cultivars produced in the lower basin of the São Francisco Valley. Revista Ciência Agronômica 46: 176-184.

Bouzo, C.A., Céccoli, G., Muñoz, F. 2018. Effect of potassium and calcium upon the yield and fruit quality of Cucumis melo. Agriscientia 35: 25-33.

Brackmann, A., Anese, R.O., Both, V., Thewes, F.R., Fronza, D. 2012. Atmosfera controlada para o armazenamento de goiaba cultivar 'Paluma'. Revista Ceres 59: 151-156.

Cavalini, F.C., Jacomino, A.P., Trevisan, M.J., MigueL, A.C.A. 2015. Ponto de colheita e qualidade de goiabas 'Kumagai' e 'Paluma'. Revista Brasileira de Fruticultura 37: 64-72.

D'Egidio, S., Galieni, A., Stagnari, F., Pagnani, G., Pisante, M. 2019. Yield, Quality and Physiological Traits of Red Beet Under Different Magnesium Nutrition and Light Intensity Levels. Agronomy 9: 379.

Dias, T.J., Cavalcante, L.F., Leon, M.J., Santos, G.P., Albuquerque, R.P.F. 2011. Produção do maracujazeiro e resistência mecânica do solo com biofertilizante sob irrigação com águas salinas. Revista Ciência Agronômica 42: 644-651.

Foloni, F.S.S., Corte, A.J., Corte, J.R.N., Echer, F.R., Tiritan, C.S. 2013. Adubação de cobertura na batata-doce com doses combinadas de nitrogênio e potássio. Semina 34: 117-126.

IBGE. Instituto Brasileiro de Geografia e Estatística. 2017. Produção agrícola municipal, estadual e nacional. 
http://www.ibge.gov.br/estadosat/<Access on 20 Apr. 2019>

Instituto Adolfo Lutz. 2008. Métodos físico-químicos para análise de alimentos. Instituto Adolfo Lutz, São Paulo, Brazil. 1020 p.

Lima, M.A.C., Bassoi, L.H., Silva, D.J., Santos, P.S., Paes, P.C., Ribeiro, P.R.A., Dantas, B.F. 2008. Effects of levels of nitrogen and potassium on yield and fruit maturation of irrigated guava trees in the São Francisco Valley. Revista Brasileira de Fruticultura 30: 246-250.

Machado, T.F., Monteiro, E.R., Tiecher, A. 2019. Estabilidade química, físico-química e antioxidante de polpa de Physalis pasteurizada e não pasteurizada sob congelamento. Brazilian Journal of Food Technology 22: e2017149.

Malta, A.O., Araújo, R.C., Medeiros, J.G.F., Costa N.P., Azerêdo, L.P.M., Dias, J.A. 2013. Características químicas dos frutos da goiabeira 'Paluma' em função da adubação orgânica e mineral. Revista de Educação Agrícola Superior 28: 120-125.

MAPA. Ministério da Agricultura, Pecuária e Abastecimento. 2000. Instrução normativa n. 01, de 07 de janeiro de 2000. http://www2.agricultura.rs.gov. br/uploads/126989581629.03_enol_in_1_00_mapa. doc./<Access on 20 Feb. 2019>

Nascimento, J.A.M., Cavalcante, L.F., Dantas, S.A.G., Medeiros, S.A.S., Dias, T.J. 2015. Biofertilizante e adubação mineral na qualidade de frutos de maracujazeiro irrigado com água salina. Irriga 20: 220-232.

Natale, W. 2009. Adubação, nutrição e calagem na goiabeira. In: Natale, W., Rozane, D.E., Souza, H.A., Amorim, D.A. (ed.). Cultura da goiaba do plantio à comercialização. UNESP-FCAV, Jaboticabal, Brazil. p. 257-280.

Onias, E.A., Teodosio, A.E.M.M., Bomfim, M.P., Rocha R.H.C., Lima, J.F., Medeiros, M.L.S. 2018. Revestimento biodegradável à base de Spirulina platensis na conservação pós-colheita de goiaba Paluma mantidas sob diferentes temperaturas de armazenamento. Revista de Ciências Agrárias 41: 281-290.

Pérez-Barraza, M.H., Osuna-García, J.A., Padilla-Ramírez, J.S., Sánchez-Lucio, R., Nolasco-González, Y., GonzálezGaona, E. 2015. Fenología, productividad y calidad de fruto de guayaba pulpa crema y rosa en clima tropical en méxico. Interciencia 40: 198-203.

Ramos, M.J.M., Monnerat, P.H., Pinho, L.G.R., Carvalho, A.J.C. 2010. Qualidade sensorial dos frutos do abacaxizeiro 'Imperial' em deficiência de macronutrientes e de boro. Revista Brasileira de Fruticultura 32: 692-699.

Rogier, S.Y., Coetzee, Z.A., Walker, R.R., Deloire, A. Tyerman, S.D. 2017. Potassium in the grape (Vitis vinifera L.) Berry: Transport and function. Frontiers in Plant Science 8: 1629

Santana, E.A., Cavalcante, Í.H.L., Brito, D.S., Carmo, R.N., Sousa, K.S.M. 2017. Fruit production and quality of guava as a function of biofertilizer and nitrogen fertigation in semiarid. Emirates Journal of Food and Agriculture 29: 242-249.

Santos, A.P.G., Viana, T.V.A., Sousa, G.G., Gomes-do-Ó, L.M.G., Azevedo, B.M., Santos, A.M. 2014. Produtividade e qualidade de frutos do meloeiro em função de tipos e doses de biofertilizantes. Horticultura Brasileira 32: 409416.

Sediyama, M.A.N., Vidigal, S.M., Santos, M.R., Salgado, L.T. 2009. Rendimento de pimentão em função da adubação orgânica e mineral. Horticultura Brasileira 27: 294-299.

Conflict of Interest Statement: The authors declare that the research was conducted in the absence of any commercial or financial relationships that could be construed as a potential conflict of interest.

All the contents of this journal, except where otherwise noted, is licensed under a Creative Commons Attribution License attribuition-type BY. 